ICIP WORKING PAPERS:
$2012 / 6$

Peacetime Violence

in El Salvador and Honduras

A tale of two countries

Rachel Meyer

INSTITUT

CATALÀ

INTERNACIONAL

PER LA PAU 


\section{Peacetime Violence in El Salvador and Honduras A tale of two countries}

Rachel Meyer

Institut Català Internacional per la Pau Barcelona, November 2012 


\section{Institut Català Internacional per la Pau}

Gran Via de les Corts Catalanes 658, baixos · 08010 Barcelona

T. +34935544270 | F. +34935544280

recerca.icip@gencat.cat|http://www.icip.cat

\section{Editors}

Javier Alcalde and Rafael Grasa

\section{Editorial Board}

Pablo Aguiar, Laia Balcells, Alfons Barceló, Gema Collantes-Celador, Caterina Garcia, Abel Escribà, Tica Font, Antoni Pigrau, Xavier Pons, Alejandro Pozo, Mònica Sabata, Jaume Saura, Josep Maria Terricabras and Léonie Van Tongeren

\section{Translation}

Charles Sothgate

\section{Graphic Design}

Fundació Tam-Tam

Typesseting and printing

Ātona, S.L. / gama, sl

\section{ISSN}

2013-5793 (online edition)

2013-5785 (paper edition)

\section{DL}

B-33.221-2012 


\section{THE AUTHOR}

Rachel Meyer holds a BA in Political Studies from Bard College in New York and a Master's degree in International Relations from the Barcelona Institute for International Studies (IBEI). This paper is based on her Master's dissertation, supervised by Rafael Grasa, and represents part of an ongoing research project related to understanding violence and related public policies.

\section{ABSTRACT}

The end of the Cold War did not bring about an end to violence in Central America. Today, so-called non-political violence continues to worsen. Academics and public policymakers are frequently influenced by the assumption that there is a causal relationship between the political violence of the 1980 s and the non-political violence of today. By looking at the cases of El Salvador and Honduras, this working paper seeks to systematize existing claims about the causal relationship between past and present violence into two approaches. Our research shows that high levels of prolonged political violence, along with an abundance of firearms, can lead to high levels of prolonged non-political violence but not in the ways most often cited in existing literature. We propose a new model to better understand the connection between past and present violence and recommend indicators that can be used to measure variations in violence over time in contexts of protracted non-political violence.

Keywords: chronic violence, political violence, El Salvador, Honduras 


\section{RESUMEN}

El final de la Guerra Fría no puso fin a la violencia en América Central. Hoy en día, el nivel de la llamada violencia no política continúa empeorando. Académicos y políticos suelen tomar como punto de partida la existencia de una relación causal entre la violencia política de la década de 1980 y la actual violencia no política. Al observar los casos de El Salvador y Honduras, esta investigación pretende sistematizar los argumentos existentes en dos escuelas teóricas para valorar si existe una relación causal entre la violencia actual y la pasada. La investigación indica que la violencia política prolongada y el fácil acceso a las armas de fuego pueden dar lugar a violencia no política prolongada, pero no de la manera que suele aparecer en la literatura existente. Proponemos un nuevo modelo para entender mejor la conexión entre la violencia política y la no política, con indicadores que pueden ser utilizados para medir en el tiempo las variaciones de la violencia en contextos de violencia no política.

Palabras clave: violencia crónica, violencia política, El Salvador, Honduras

\section{RESUM}

El final de la Guerra Freda no va posar fi a la violència a Amèrica Central. Avui dia, el nivell de l'anomenada violència no política continua empitjorant. Acadèmics i polítics solen prendre com a punt de partida l'existència d'una relació causal entre la violència política de la dècada de 1980 i l'actual violència no política. En observar els casos del Salvador i Hondures, aquesta investigació pretén sistematitzar els arguments existents en dues escoles teòriques per valorar si hi ha una relació causal entre la violència actual i la passada. La investigació indica que la violència política prolongada i el fàcil accés a les armes de foc poden donar lloc a violència no política prolongada, però no de la manera que sol aparèixer en la literatura existent. Proposem un nou model per entendre millor la connexió entre la violència política i la no política, amb indicadors que poden ser utilitzats per mesurar en el temps les variacions de la violència en contextos de violència no política.

Paraules clau: violència crònica, violència política, El Salvador, Honduras 


\section{CONTENTS}

1. INTRODUCTION

2. LITERATURE REVIEW AND ANALYTICAL FRAMEWORK 9

2.1. APPROACH 1: THE TANGIBLE LEGACY OF POLITICAL VIOLENCE 12

2.2. APPROACH 2: THE INTANGIBLE LEGACY OF POLITICAL VIOLENCE 19

3. CASE BACKGROUND 24

3.1. CASE 1. HONDURAS 25

3.2. CASE 2. EL SALVADOR 29

3.3. SUMMARY 32

4. PROPOSAL FOR AN INTEGRATED MODEL AND INDICATORS 33

4.1. CRIME UNDERREPORTING 34

4.2. CONFIDENCE IN STATE INSTITUTIONS: THE JUDICIARY (4.2A) AND THE POLICE (4.2B) 35

4.3. IMPROVED ESTIMATES ON LEGAL AND ILLICIT FIREARMS 37

4.4. POLICY IMPLICATIONS 5

4.4A. CURRENT PUBLIC POLICIES IN EL SALVADOR 42

4.4B. CURRENT PUBLIC POLICIES IN HONDURAS 42

4.5. SUMMARY $\quad 43$

5. CONCLUSION

6. REFERENCES $\quad 45$ 



\section{INTRODUCTION}

This paper sets out to explore the relationship between political and non-political violence in post-civil or quasi-civil war settings, especially in Central America. The problem has had many diagnoses and even more treatments, as academics and public policymakers try to address a very real problem. Unfortunately, the violence seems to only worsen. This paper seeks to explore whether persistent levels of non-political violence can be explained, in part, as legacies of past violence. More specifically, this paper asks whether the existing literature sufficiently explains the connection between present and past violence and if not, how to improve upon existing explanations.

It is widely acknowledged that violence is caused by many interrelated variables, and must be understood as a product of the interplay between dynamic and mutually reinforcing factors. The World Bank, for example, explains the causes of violence in the following way:

The high levels of crime and violence that currently exist in [Latin America] can be attributed to a complex set of factors, including rapid urbanization, persistent poverty and inequality, social exclusion, political violence, organized crime, post-conflict cultures, the emergence of illegal drug use and the trafficking and authoritarian family structures. (2008:3)

However, to gain insight into a complex issue, its individual components must also be separated out and understood in order to then assess their interplay. Thus, this paper will focus on the specific connection between past political violence and current non-political violence, while acknowledging that it is just one small piece of a much broader issue.

Most discussions of violence in Central America include a causal connection between current violence and the extensive political violence of the 1980 s. Such claims are regularly espoused as though selfevident, without much analysis or empirical evidence. Meanwhile, newer research on violence suggests that while it is causally connected 
to past violence (reproduced in a variety of social spaces and transmitted through time), protracted political violence is an extraneous factor (see Pearce 2007). In other words, violence begets violence but topdown political violence does not have an independent effect.

El Salvador and Honduras make ideal case studies for this project because the nations have the most similarities today in Central America, in terms of social indicators and the degree of violence, and both have experienced high but varying levels of protracted political violence and repression in the 1980s. Additionally, the theories explored in this project have not yet been applied to these cases. In the following chapters, the evolution of violence will be explored by trying to unpack the claimed causal links between protracted political violence (if it is in fact relevant) and current direct non-political violence. As such, the conclusions that come out of this research could be potentially relevant beyond Central or even Latin America to any post-conflict setting where a recent influx of arms into the hands of new actors could have long-lasting societal consequences. Though policies geared at reducing endemic violence must be carried out thoughtfully and on a case-by-case basis, scholars and policymakers can look to other cases for input.

The methodology for this project was built on two types of research. Predominately, research was undertaken through the assessment of statistical and survey information available through the World Bank, the Pan American Health Organization, LatinoBáromentro, and other relevant publications. Secondly, an original, semi-structured interview with Salvador Samayoa was carried out. Though it must be acknowledged that one interview is hardly representative and a wider range of interviews can be undertaken in future research, a discussion with Samayoa on this topic was a unique opportunity and his firsthand experiences offer special insight. Samayoa has been a public figure in El Salvador in a variety of capacities since the late 1970s, starting with a brief stint as Minister of Education under the Junta de Gobierno in 1979 before defecting to become a political leader of the Frente Farabundo Martí para la Liberación Nacional (FMLN), the Salvadoran guerilla movement. He participated in all the peace negotia- 
tions between the FMLN and the Salvadoran government during the 1980s, including the final and successful UN-brokered Peace Accords, which he also signed. After the civil war, he supervised the implementation of the Accords for the FMLN and continued to hold other political roles including President of the National Council of Public Security. Although the complete interview with Samayoa could not be included, relevant fragments are integrated throughout the text in text boxes.

This paper is divided into 5 chapters. Chapter 1 provides a brief introduction and an overview of the layout. Chapter 2 sets up the analytical framework of the paper in several ways. First, it defines terminology that will be used throughout the paper. Secondly, it establishes two main ways that the existing literature link past violence to present violence: Approach 1 which claims there is a causal link between current non-political direct violence and the political violence of the 1980 s through the leftover guns and ex-combatants of the time; and Approach 2 which claims that violence is transmitted and reproduced over time in certain intangible ways. Chapter 3 presents a brief overview of recent history in El Salvador and Honduras, the two cases under review. Chapter 4 builds upon the analytical foundation explored in Chapter 2 to suggest an integrated model that would better explain the connection between past and present violence. Additionally, Chapter 4 suggests indicators to better measure the evolution of violence over time. Chapter 5 offers a brief conclusion.

\section{LITERATURE REVIEW AND ANALYTICAL FRAMEWORK}

This section attempts to systematize two ways in which scholars attribute current high levels of non-political direct violence to past violence in El Salvador and Honduras. Two patterns emerge in the literature and relevant arguments have thus been organized into two groups. Approach 1 focuses on the tangible legacies which high lev- 
els of political violence leave behind, including demobilized men, the availability of weapons and other wartime or quasi-wartime infrastructure. Newer literature, grouped into Approach 2, focuses on the intangible legacies of past violence, including a long-term process of gendered socialization, the internalization and normalization of violence and the transmission of that framework from one generation to the next. Each approach suggests a causal relationship between current non-political violence and past historical violence, yet neither sufficiently clarifies how past violence influences present violence.

Table 1 indicates definitions of terms used in this paper including civil war, conflict, crime and violence. As these are terms that can vary significantly in the literature due in part to the fact that there are no internationally agreed upon definitions to terms like violence, Table 1 is meant to provide a common framework through which the rest of the text can be understood. Of these terms, violence is the most complex to define and can be categorized in many ways such as direct, political, everyday, cultural, structural (indirect), symbolic or chronic. For the purposes of this paper, it is especially important to recognize micro-level and macro-level violence and understand how they overlap, are mutually reinforcing, trigger or reproduce one another. However it is beyond the scope of this paper to enter into this debate in more detail. ${ }^{1}$

1. A note about gender and violence: Many scholars include categories such as "social violence", "gender violence" or "domestic violence" in their typologies (see Moser 2004 for example), which is especially relevant in contexts such as Latin America where " $m a$ chista culture" is often associated with causal factors of violence. Current discussions of gender and violence may include partner violence, sexual violence and child abuse, in addition to other violent acts that may take place at home or in social spaces. While these types of violence are a grave concern and highly relevant in any discussion of violence, it is also true that all types of violence have a gendered dimension.

There is a risk in relegating violence against women and children into a "social" or "domestic" category, inadvertently reinforcing the idea of social space as women's space and obscuring how gender plays a role in all other types of violence. To borrow ScheperHughes and Bourgois' critique of the narrow treatment of violence in university curriculum, "[it] misrecognize[s] the extent to which structural inequalities and power relations are naturalized by our categorizes and conceptions of what violence really is. They also fail to address the totality and range of violent acts, including those which are part of the normative fabric of social and political life." (2004: 5) 
Table 1. Definition of Terms

\begin{tabular}{|c|c|}
\hline Civil war & $\begin{array}{l}\text { - A violent conflict within a country fought by organized } \\
\text { groups that aim to take power at the center or in a region, } \\
\text { or to change government policies (Fearon 2007). }\end{array}$ \\
\hline \multirow[t]{2}{*}{ Conflict } & $\begin{array}{l}\text { - A perceived incompatibility between parties (Galtung 1996). } \\
\text { - Moser (2004) reminds us that conflict and violence are not } \\
\text { synonyms. Both can be seen as struggles for power, but } \\
\text { conflict need not necessarily be violent. }\end{array}$ \\
\hline & $\begin{array}{l}\text { Structural causes are underlying factors that are the } \\
\text { source of incompatibility between parties. Public } \\
\text { policies that address root causes of conflict will } \\
\text { ultimately be most effective. } \\
\text { - Necessary causes must be in place in order for conflict } \\
\text { to erupt. For example, for gun homicides to significantly } \\
\text { increase, there must be widespread and easy access to } \\
\text { firearms. } \\
\text { - Sufficient causes of conflict or Triggers of different } \\
\text { phases of conflict can lead most directly to violence. These } \\
\text { types of causes are the most difficult to understand with } \\
\text { precision because they can vary from one context to } \\
\text { another. (Grasa 2010) }\end{array}$ \\
\hline Crime & $\begin{array}{l}\text { - A legal category that varies from place to place, though } \\
\text { often entails violence against persons or property. } \\
\text { - There is not an inherent link between crime and power, as } \\
\text { is found in the links between power, conflict and violence } \\
\text { (Moser 2004). }\end{array}$ \\
\hline Violence & $\begin{array}{l}\text { - Political Violence is used here to mean intimidation, } \\
\text { repression, or direct violence perpetrated with the explicit } \\
\text { or implicit consent of state agents for a political aim. } \\
\text { Political violence can target individuals for their beliefs or } \\
\text { affiliations, but it can also be used indiscriminately at the } \\
\text { public to instill fear or warn against certain behaviors. } \\
\text { - Non-Political Direct Violence includes physical harm } \\
\text { done to people without a political aim. (Author's elaboration) }\end{array}$ \\
\hline
\end{tabular}

Source: Author's elaboration based on references cited. Definitions of violence by the author. 


\subsection{APPROACH 1: THE TANGIBLE LEGACY \\ OF POLITICAL VIOLENCE}

Approach 1 is made up of several main threads that suggest a causal connection between the political violence of the 1980 os and the level of non-political violence today: leftover weapons (in the wrong hands), demilitarized ex-combatants (who may not have jobs but may have some military-style training), and organized crime (made possible by wartime smuggling routes).

Available data suggests that social violence and armed criminality are on the rise in the aftermath of the conflicts that have plagued most countries of [Central America]. In the early twenty-first century, politicized factions that fought in the 1980 s are giving way to criminal gangs and organized civilian militia groups that are taking advantage of left-over military-style weapons, including grenades. Disenfranchised ex-combatants and unemployed or otherwise marginalized male youths are easily recruited into such groups. (Godnick, Muggah and Waszink 2002: vii)

The idea that violent groups with a political aim are suddenly left without a purpose and morph into criminal organizations runs throughout much of the literature. It is also often argued that leftover wartime weapons are then used by groups participating in criminal activity, though as will be discussed in more detail, this assumption is anything but clear.

These themes recur in explanations of current violence regarding countries like El Salvador, which suffered a decade of civil war, but also in literature regarding Honduras, where the politically-based violence and repression did not ultimately rise to the intensity of a civil war.

It is important to establish that the permanence of armed groups linked to anti-Sandinistas [in Honduras], throughout the entire decade of the 80 , provoked social instability and increased everyday violence. Many people cite this factor as of great importance in the circulation of easy-tobuy weapons that would later become available to common criminals in 
Honduras. This factor should be understood as an agent of violence, through which violence can be directly exercised and also as a circumstance that provokes violence. (Salomon 1993: 47-8, author's translation)

The idea that the same weapons used for political violence would later become directly appropriated and used to commit other types of direct violence is commonly cited, as well as the fact that the porous borders of the small Central American nations facilitate the opportunity for violence and weapons in one country to influence the next.

A more recent report from NACLA in 2008 continues to directly link Cold War era small arms in Central America to violence today. "The Cold War and its legacies bear most of the responsibility [for the overflow of weapons which] represent the most dramatic threat to public safety" (Stohl and Tuttle 2008: 14). Furthermore, the report goes on to claim that

[these weapons are] responsible, in part, for the crime and violence that has retarded development throughout Latin America. These weapons last longer than their intended purposes require, perpetuating cycles of violence and underdevelopment that affect the entire region. (Ibid., 20)

According to this logic, current violence, aided by available weaponry leftover from the 1980 s, is a direct result of the civil wars in the region.

In addition to ex-combatants taking up organized crime and leftover weapons falling into the wrong hands, a 2012 report from the preeminent American think tank Council on Foreign Relations argues that current smuggling routes, needed to finance and facilitate illicit activities, are a direct result of the wartime infrastructure.

Organized crime...is one clear legacy of the region's war-torn past. Internal armed conflicts in Guatemala and El Salvador featured counterinsurgency campaigns, carried out by military forces supported by paramilitary units and robust intelligence services. Subsequent efforts to build solid democratic institutions failed to dismantle these structures, which 
have turned to a host of illicit enterprise, including drug smuggling, human trafficking, illegal adoptions, arms smuggling, and movement of other contraband. (Shifter 2012: 5)

The recurring theme of the tangible legacies of regional wars in the 1980 s playing a direct role in current non-political violence is a regular feature in academic literature and news reporting on the region. Above, this type of thinking has been organized into a framework entitled Approach 1 which lays out its casual logic, and the following section will delve more deeply into a discussion of its weak points.

\section{LIMITATIONS TO APPROACH 1}

Though the arguments behind Approach 1 make intuitive sense, the link between wartime infrastructure and current violence remain empirically unclear. The main arguments that make up this framework are concrete tangible legacies of political violence (ex-combatants, leftover weapons, smuggling routes), so it stands to reason that empirical evidence should lend significant support to this line of thinking. However, available evidence regarding all three main arguments suggests that this causal link is unclear at best.

The first piece of Approach 1, that some unemployed ex-combatants became gang members, is the most clearly documented, yet the argument for causality of current violence remains unclear. Richani points out that a study of incarcerated criminals in the late 1990s suggested that having participated in the Salvadoran civil war increased the probability of committing a homicide in its aftermath, yet $70 \%$ of the population did not participate in the civil war. Furthermore, throughout the 1990s, the average age of criminals was between 15 and 21, suggesting that the majority were too young to have been combatants during the war (2010: 434). This finding indicates that ex-combatants were not directly responsible for the majority of homicides committed in the immediate aftermath of the war and the correlation only weakens over time as ex-combatants grow older but the majority of crimes continue to be committed by young men. 
Regarding available weaponry, recent investigative reporting and official US government documents made public through WikiLeaks suggest that military-style weapons, including grenades, anti-tank weapons, M-16s and G36s, were sold by the US to Honduras in the 1980 s and early 1990 s and have recently been found in the hands of organized crime groups in Mexico, Guatemala and Colombia. However, according to the United States Alcohol, Tobacco and Firearms agency (ATF), AK-47s are the most commonly used weapon by cartels in Mexico, which are produced in China and Romania, sold legally within the US, and then smuggled south (Ramsey 2011). It stands to reason that if well-financed organized crime groups in Mexico are not predominately carrying military-style weapons, local gangs in El Salvador and Honduras are not either. It is clear that Central American governments like Honduras' are not doing nearly enough to control the leftover weapons that they do possess, but the majority of gun violence across Central America and Mexico is not committed with military-style weapons.

Anecdotal evidence provided by Salvador Samayoa, former FMLN political leader during the insurrection and signer of the peace accords suggests that the type of weapons being used in common crimes in El Salvador today are simply not of the same caliber as wartime weapons. In fact, he expressed great pride to the author about the advanced military-style weapons which were standard in the FMLN arsenal, and he pointed out that those are simply not associated with local gangs today. He went on to say that the FMLN turned in their weapons at the end of the Salvadoran civil war as stipulated in the peace accords, which he personally oversaw (Samayoa, author interview 2012). Without evidence to the contrary, it seems that more recent legal imports and illicit sales may be a more urgent cause for concern.

There is an important distinction to be made in terms of illicit firearms in El Salvador and Honduras which often goes unnoted. A local research team, with outside funding from the government of Finland, concluded that legal firearms are so easy to come by in El Salvador, there is simply less of a black market then in neighboring countries (Marbley Martínez 2006: 11). The study goes on to cite periodic de- 
crees by the legislative assembly that have successfully allow for noquestions-asked firearms registration, leading local officials to believe that there are only "minimum levels" of illegal arms trafficking occurring in El Salvador. A similar conclusion was reached in a 2008 UK report regarding the Salvadoran gun buyback program in the late 1990s known as Goods for Guns. "The relative success of the Goods for Guns programme was offset by the high levels of gun ownership in the country. 48,620 more new firearms were legally imported into El Salvador than those turned in during Goods for Guns." (CICS 2008:17) The black market in Honduras, however, appears to be thriving, and seized weapons have disappeared in alarming quantities from official control.

Putting aside for a moment the source of weapons in use today, the causal relationship between the number of guns available and the number of gun homicides committed is not completely clear (see Chart 1). Gun availability is undoubtedly an important factor in gun homicide and effective public policies are desperately needed that can address this matter. As outlined in the Definition of Terms section, gun availability is a necessary cause for high levels of gun violence, but

Chart 1. Rates of gun homicide and gun ownership

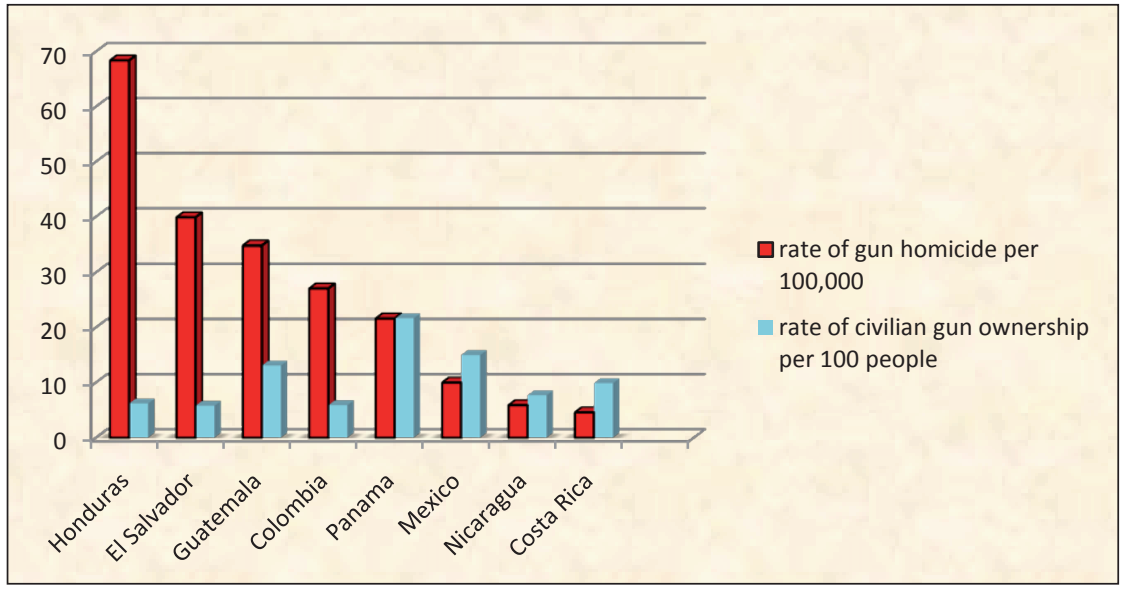

Source: Author's elaboration based on data from www.gunpolicy.org 
it is not a sufficient cause. This means, logically, that in order to have a context in which gun violence in prevalent, guns must be available. Yet, as Chart 1 suggests, gun prevalence itself does not appear to cause high homicide rates.

Chart 1 compares the rate of gun homicides to the rate of gun ownership, indicating prevalence of firearms. The data suggests that increased firearm prevalence is not a sufficient cause of increased gun homicide rates. The so-called "Northern Triangle" (El Salvador, Guatemala and Honduras) have far higher gun homicide rates despite relatively similar rates of ownership across Central America and other parts of Latin America. It should be noted that in countries where gun homicides make up $70 \%$ or more of total homicides, the homicide rates in those countries are disproportionately high (over 20\% per 100,000) (Global Burden of Armed Violence 2011: 7). This finding establishes a strong correlation between high gun homicide rates and high homicide rates overall, but it does not suggest a causal connection between the number of guns available and the number gun homicides.

As previously mentioned, some scholars assert that weapons, drugs and other contraband being pushed through Central America today is only possible due to the routes created by warring factions seeking weapons and supplies in the 1980s. Salvador Samayoa, based on his firsthand experience, refutes the existence of a causal relationship between the war and the smuggling routes. Instead, he argues that smuggling routes were around long before the war, and thus calls into question the causal connection between past political violence and those routes.

In sum, Approach 1 is an attempt to systematize existing causal claims about the link between leftover weapons, ex-combatants and infrastructure such as smuggling routes and current non-political violence. Once it is organized into a logical framework, its validity can be assessed. A careful look at Approach 1 reveals that although a causal link between the tangible infrastructure of political violence and current non-political violence makes intuitive sense and is often cited, it lacks a necessary degree of empirical evidence to sustain sufficient 
Box 1. Questioning the Connection Between the Tangible Legacies of Political Violence and Current Violence: An Insider's Perspective

In this part of the interview, Samayoa references a recent debate with Douglas Farah at the Wilson Center, an American think tank. Farah is one of many experts who have asserted that current violence (especially with regard to organized crime) is a clear legacy of the war because smuggling routes, the personnel who operate them and the weapons available are remnants of the period.

I told [Farah] that those ideas were completely and absolutely false. The war didn't create the networks of smuggling routes and so their existence is not a consequence of the war. They are intraregional trade networks that can also be used towards illicit ends that don't have anything to do with trade. We [the FMLN] used them to bring in weapons, we used those networks and people all the time...No one from the military establishment from that period nor any of the FMLN leaders would have anything to do with organized crime. And that's what I was saying in Washington, that establishing this relationship between organized crime... and the war, or remnants of the war isn't valid. Nor is it valid in terms of weapons. There is a list that anyone can look up that shows that we had really sophisticated weapons. We turned in thousands of weapons, thousands of infantry weapons and hundreds of missiles. We had submachine guns of about .50 and .30 caliber; we had canons and grenade launchers. And all the weaponry that we turned in is not the same that is being used now in drug trafficking, etc. So, there is just no way, no way to establish that connection.

credibility. The anecdotal evidence offered by Samayoa is not in it of itself enough to counter the theories put forward in Approach 1, but do support what has become apparent given the other weaknesses of the causal claims.

It is also worth noting that many scholars include poverty and inequality as important causal factors for current violence, in addition to tangible Cold War legacies. In fact, one author goes so far as to directly 
refute any causal connection between wars and current levels of crime in Central America, instead arguing that inequality is a better predictor of homicides in Central America (Cardenal Izquierdo 2008). Yet, the latest GINI Index available shows that Costa Rica is more unequal than El Salvador, yet Costa Rica's homicide rate is less than 1/5 of El Salvador's (Central Intelligence Agency (n.d.); United Nations Office on Drugs and Crime 2010). Furthermore, many other countries in Latin America and elsewhere face similar or worse levels of poverty and inequality and do not register anywhere near the same level of violence. Though it has been broadly accepted that there is a correlation between poverty and inequality and direct violence, this single variable cannot sufficiently explain all cases to the exclusion of other causal factors. It is beyond the scope of this paper to further assess the link between poverty and violence or to establish the extent to which it is relevant.

\subsection{APPROACH 2: THE INTANGIBLE LEGACY OF POLITICAL VIOLENCE}

Alternatively, the relatively new theory of "Chronic Violence", put forward by Jenny Pearce in 2007, provides an innovative perspective. She identifies and defines a type of violence that emerges from and is sustained by extensive and prolonged violence.

[Chronic violence is] where rates of violent deaths are at least twice the average for high and low income countries respectively; where these levels are sustained for five years or more and where frequent acts of violence not necessarily resulting in death, are recorded across several socialization spaces, including the household, the neighbourhood, the school, inter community and the nation state public space (which brings in disproportionate, sanctioned and non sanctioned acts of violence attributed to state security forces). (Pearce 2007: 07, footnote 4)

This concept suggests that pervasive and prolonged violence effects society on many levels (not just the victims and their families). Fur- 
thermore, Pearce's theory requires taking multiple forms of violence into consideration and suggests looking at violence across multiple spaces.

In the 2011 publication "Chronic Violence and its Reproduction: Perverse Trends in Social Relations, Citizenship and Democracy in Latin America”, Adams builds on Pearce's theory and refutes Approach 1.

The World Bank's recent study of violence in Central America [...] notes that while armed conflict in the region may have contributed to increased violence by damaging criminal justice institutions and generating a large stock of guns that remain in circulation, broader evidence does not suggest that the region's high levels of violence are principally a legacy of armed conflict. (Adams 2011: 23, emphasis added)

Instead, she argues that an overemphasis on procedural democracy and institutional strength in Latin America may inadvertently distract from dealing with the causal roots of violence. If this is true, the vast amount of time and resources spent on strengthening state institutions to facilitate liberal democracy are misdirected and incapable of solving the root of the problem. Alternatively, she argues that attitudes towards violence and a lack of social capital, among other factors, may explain persistent non-political violence in Central America.

An important aspect of the theory of Chronic Violence is that the concept of violence and attitudes towards it can be transmitted intergenerationally. Its transmission impacts men and women in different but specific ways and is shown with great clarity in Dickson-Gómez's 2002 field research in rural El Salvador. She noted that "expectations of violence and state oppression" are passed from one generation to the next by creating a framework in which to process current events or justify actions (2002: 415-6). In her observations of personal reactions to homicides in the local community or on the news, many believed that the perpetrators were soldiers or ex-guerrilla fighters and the events were referred to as evidence that another war was coming. These conversations, regularly had in front of children, kept the wartime mindset alive and perpetuated fear and distrust (Ibid.: 423-4). 
These different aspects of Approach 2 suggest a different framework for understanding the connection between past and present violence, where present violence is sustained and varied in nature. According to this argument, an overemphasis on procedural democracy after the end of the Cold War and a failure to address the intangible effects of violence, therein permitting their chronic reproduction, have caused violence to continue unabated. Below (Box 2), an excerpt from the Samayoa interview lends some anecdotal credibility to Approach 2. Ultimately, understanding the causal relationship between past and present violence, in so far as it is possible to do so, will provide the best opportunity to craft public policies to effectively break the cycle.

In sum, Approach 2 considers the connection between past and present violence irrespective of prolonged war or pervasive political violence. Violence (not only homicide) is taken into consideration in many different types of state, public social and private spaces. It also

Box 2. The Connection Between the Intangible Legacies of Political Violence and Current Violence: An Insider's Perspective

In this part of the interview, I broadly explained the theory of Chronic Violence to Samayoa and asked if he thought it had any legitimate explanatory power given his close experiences in El Salvador.

On the other hand, the question that you ask me about the other dimension of violence, more social, more quotidian, more related to the gangs, etc., I think there is a connection between a period of war during which an entire generation grew up with the idea that life isn't worth anything and that anyone could be killed, then what the army did during the $80 \mathrm{~s}$ when death squads appeared and dead bodies thrown into bags or mutilated appeared everywhere. It was a grotesque thing to get used to...and it prompted people to see death differently and to see life differently...It's not like flowers are coming out of your gun in a war. It was ten long years of war. I think that did leave a psychosocial-psychological mark. 
argues that the way violence is normalized and passed from one generation to the next maintains its elevated intensity. Its explanatory advantages over Approach 1 include its ability to mix empirical data, such as homicide rates, with intangible legacies such as violence transmission. However, as will be discussed in more detail in the following section, in order for Approach 2 to become operational, more structure and measurable indicators are needed.

\section{LIMITATIONS TO APPROACH 2:}

Although Approach 2 considers types of violence besides homicide rates, they do play a factor as an aggregate measurement in order to identify contexts of Chronic Violence. One challenge to using homicide rates as an aggregate measure in terms of Chronic Violence is that it may obscure certain trends which are relevant for context-sensitive understandings of violence. Chart 2 disaggregates homicide statistics by looking at total numbers of external causes of mortality in El Salvador, excluding car accidents. If violence has been transmitted and reproduced through society over time, we would expect homicides to

Chart 2. 3 Most Common External Causes of Mortality in El Salvador

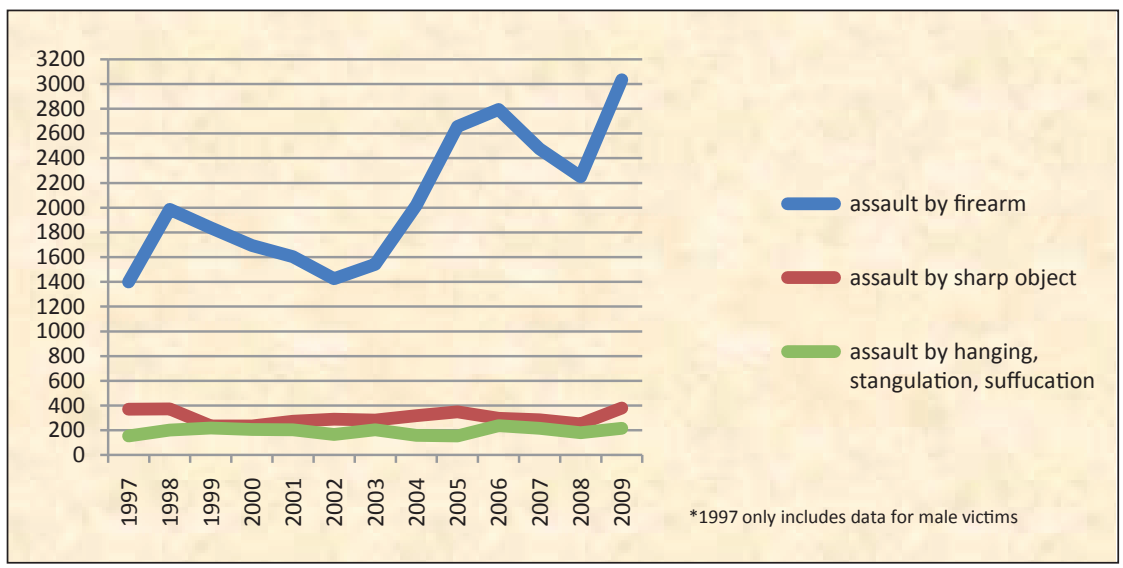

Source: Author's elaboration based on data from the Pan American Health 
increase by all methods. Yet available data demonstrates that firearm homicides have disproportionately increased, suggesting that, in terms of violent death, firearms play a special role which cannot be explained by the current theory of Chronic Violence.

As previously mentioned, Chronic Violence requires us to not use homicide rates as the sole proxy for violence in a nation, an idea echoed by Valenzuela's analysis of violence in Colombia. He writes "a general analysis of the impact of cultural values on violence should be based not only on the violent acts that take the most life, but also on the acts that most affect people" (2002: 130, author's translation). Yet there are practical limitations imposed by available data that tie researchers to homicide rates in order to compare cases. Pearce (2007) overcomes this problem by using homicide statistics in conjunction with qualitative interviews, yet this mixed method could be enriched by additional quantitative indicators to create a consistent framework that could be used to compare cases in addition to being context-sensitive. These indicators might include data on crime underreporting, confidence in state institutions and estimates on legal and illicit firearm ownership. Chapter 4 of this Working Paper is set aside for a fuller discussion of how each of these indictors could be used and why their inclusion is important.

Another challenge that Approach 2 faces is that there is no clear trigger or starting date to mark the beginning of chronic violence, making measurements and operationalization a challenge. Working backwards, the definition indicates that chronic violence is measured by five years of homicide rates that are twice the average for the income group of the country. In El Salvador, for example, homicide rates during the war were similar to or higher than what they are today and shot up in 1996 to 126 homicides per 100,000 people, 4 years after the war ended. Given that the theory of chronic violence is path dependent, claiming that violence begets violence, civil wars or protracted periods of political violence that go along with high homicide rates cannot be discounted as having no connection to current violence. 


\section{CASE BACKGROUND}

In 2011, Honduras held the title of murder capital of the world and El Salvador enjoyed the number two spot. As the two nations made their way up the ranks in recent years, the increasing gravity of the problem has garnered much attention from analysts and experts seeking to explain the causes and effects of the problem and offer policy solutions in hopes of reversing the trend. There was great hope that with the end of the Central American civil wars as well as democratic transitions throughout Latin America, the region would become more peaceful. Unfortunately, even though an uptick in direct violence can be expected in the immediate aftermath of a civil war, the amount of direct violence far surpasses what could be considered a standard trajectory.

According to the UN Office on Drugs and Crime (UNOCD), El Salvador and Honduras have the highest homicide rates in not only Latin America, but in the world outside of war zones, with 66 and 82.1 homicides per 100,000 inhabitants, respectively. To put those numbers in perspective, see Table 2. Furthermore, homicide rates are not the only similarities between the two nations, (see Table 3 for current social indicators).

Table 2. Homicide Rates 2011

\begin{tabular}{|l|c|}
\hline Country & $\begin{array}{c}\text { Homicide rate } \\
\text { (per 10o,ooo inhabitants) }\end{array}$ \\
\hline Honduras & 82.1 \\
\hline El Salvador & 66 \\
\hline South Africa & 33.8 \\
\hline Mexico & 18.1 \\
\hline USA & 5 \\
\hline Spain & 0.9 \\
\hline
\end{tabular}

Source: Author's elaboration based on UNOCD data 
Table 3. Social Indicators

\begin{tabular}{|l|c|c|}
\hline & El Salvador & Honduras \\
\hline Adult literacy rate & $84 \%$ & $84 \%$ \\
\hline Adolescents/whole population & $24 \%$ & $23 \%$ \\
\hline Life expectancy & 72 & 73 \\
\hline GDP/capita & $\$ 3702$ & $\$ 2226$ \\
\hline
\end{tabular}

Source: Author's elaboration based on World Bank data

Given these current similarities in terms of the composition of the population, economic and social similarities, as well as relatively similar levels of homicide, these two cases are clearly sufficiently similar to provide the foundation upon which to explore the connection between political and non-political violence.

One clear difference between these neighboring countries is that El Salvador underwent a protracted civil war and Honduras did not. However, looking qualitatively at each nation's history reveals that the level of protracted political violence in Honduras and the effects of various regional civil wars were severe enough to provoke similar consequences to those seen in El Salvador, an argument which will be further developed in section 3.1. For the purposes of this paper, we are interested in protracted political violence in a civil war context or otherwise, not in civil wars themselves.

\subsection{CASE 1. HONDURAS}

Although Honduras did not endure a long civil war like most of its neighbors in the Cold War-era, a close look at Honduran politics, policies and history from the 1980 s reveals that Honduras suffered significantly from political violence and from the consequences of regional civil wars. Like many other Latin American nations, Honduras was regularly ruled by its military during the Cold War era. Despite not having a formal military until the 1950 , that institution was able to write its autonomy into the Honduran constitution and controlled the country with the active or tacit approval of other elites until the early $1980 \mathrm{os}$. 
Honduras began transitioning to democracy in the early 1980s under pressure from the US, giving way to a civilian led government and the creation of a National Assembly. Also around 1980, civil wars were escalating in El Salvador and Nicaragua, bordering Honduras to the southwest and southeast respectively. ${ }^{2}$ Refugees fleeing the violence ran to Honduras, though their point of origin dictated their treatment upon arrival. Given that an extreme right wing government was in power in El Salvador, refugees from that country were considered communist sympathizers in Cold War speak, and were mostly placed in refugee camps near the Salvadoran border. Conversely, the successful communist revolution in Nicaragua in 1979 signified that refugees from that country were ideological allies to the Honduran government and were granted freedom of movement and even jobs within Honduras (Salomon 1993: 45).

In keeping with Cold War logic, the Honduran National Security doctrine of the time identified threats solely along ideological lines and labeled as enemies anyone who would "ffeed' the Central American crisis" (Ibid.: 45). Moreover, state actors in Honduras used violent and repressive methods against their domestic opponents, undermining the recent push towards institutionalizing democracy. Castellano writes this was not simply reinstating practices from the repressive military rule, but that things had taken a darker turn. There was a shift from sending political opposition into exile to "disappearing" people considered ideologically opposed to the government (Ibid.: 7). The implementation of such tactics was a direct result of the "best practices" learned by Honduran military elites during training in Argentine dirty war methods and at the notorious School of the Americas (Pine 2008: 50).

US military aid to Honduras shot up in the early 1980 s (see Table 4) and the US used Honduran military bases as part of their own regional strategy to fight communism through covert operations. As previously mentioned, local anti-communist elites were not only con-

2. Guatemala is the only other country that shares a border with Honduras and was also undergoing a 36-year civil war, from 1960-1996, meaning that Honduras was surrounded on all sides by nations at war. 
Table 4. US Military Aid to Honduras

\begin{tabular}{|l|c|c|c|c|c|c|c|}
\hline & 1980 & 1984 & 1986 & 1989 & 1993 & 1994 & 1995 \\
\hline $\begin{array}{l}\text { U.S. } \\
\begin{array}{l}\text { Military } \\
\text { Aid to } \\
\text { Honduras }\end{array}\end{array}$ & $\$ 3.9 \mathrm{~m}$ & $\$ 77 \mathrm{~m}$ & $\$ 88.1 \mathrm{~m}$ & $\$ 41.1 \mathrm{~m}$ & $\$ 2.7 \mathrm{~m}$ & $\$ 500,000$ & $\$ 325,000$ \\
\hline
\end{tabular}

Source: Author's elaboration based on data from Ruhl 2010

cerned with their neighboring countries, but also spent domestic resources to stamp out the leftist guerilla movement in Honduras. The local leftist insurgency never grew to have as much support or as many combatants as in neighboring countries, with only 300 active combatants divided among several groups at their peak. They were effectively wiped out by the military and had no chance of accomplishing their stated goals through armed insurgency, and gave up their arms by May 1990 (Allison 2006: 149-50). ${ }^{3}$

On the domestic front, the US-funded Battalion 316 was a local death squad in charge of capturing "suspected subversives" in unmarked vehicles and took them to secret jails where they would be interrogated, tortured and "disappeared" (Pine 2008: 50-1). Honduras was not officially at war and troubling events were happening on a much smaller scale than in neighboring warzones, however, at minimum, 184 people were disappeared or extra-judicially killed and many more abducted and tortured. Two rounds of amnesty laws were passed in 1987 and 1991, shielding those responsible from legal prosecution. A few legal cases made their way through the court system and the amnesty laws were overturned in 2000, after which the government agreed to pay reparations to just 19 families. Unfortunately, impunity continues to be more common than justice and known members of

3. Allison (2006) makes the interesting observation that the success of left-leaning political parties across Central America today is closely correlated to the success of the guerrilla movements from the 1970 s and 1980 s, as most modern leftist political parties were formed out of those insurgencies. Given this information, the apparent limitations of the Honduran political left today is not surprising. 
Battalion 316 remain in the public eye with connections to political leaders (Center for Justice and Accountability n.d.).

As seen in Table 4, US military aid to Honduras dropped off dramatically after the end of the Cold War and troop size was cut by more than half. Also, like many of its neighbors, Honduras undertook some reforms, such as creating a demilitarized police force. Unfortunately, this and similar steps toward "procedural democracy" did not help democratic institutions gain legitimacy (Ruhl 2010: 50). Perception of public and political sector corruption consistently ranked between 1.7 and 2.7 from 1998 to 2011, o being perceived as completely corrupt, 10 being perceived as completely uncorrupt (Transparency International n.d.). Crime and perceptions of insecurity have continued to rise, driving citizens to accept evermore-extreme anti-gang measures.

Given the gift of hindsight, it is perhaps unsurprising that 2009 saw the first successful coup d'état in Latin America in the last 15 years when President Zelaya was taken to Costa Rica in his pajamas after trying to unconstitutionally extend his term limit. The military did not impose their own leader and elections were held within the year. Despite tempered recognition of the elected government by the international community, state violence has continued and, since the coup, at least 34 members of the political opposition have disappeared, 300 citizens and at least 13 journalists have been killed by state security forces, according to the leading Honduran human rights organization, COFADEH (Frank, New York Times, January 26, 2012). Additionally, the coup distracted attention and diverted funds, both domestic and international, from urgent security concerns, leading many to observe that the coup indirectly but significantly boosted crime and insecurity (Bosworth 2010: 86).

One of the most troubling statistics concerning the small nation is that over 90\% of crimes go unpunished (Panting, La Prensa May 8, 2012; Economist 2012). The Honduran National Commission on $\mathrm{Hu}-$ man Rights cites that between 2005 and 2009, of 12,098 arrest warrants issued for human rights violations, only $20 \%$ were successfully followed through (Bosworth 2010: 80). The country's human rights ombudsman worries that Honduras is on its way to becoming a failed 
state (Economist 2012) and the alarming homicide rates, especially among the nation's young, have caused some to liken the current situation to genocide (see for example Panting, La Prensa May 8, 2012 or Pine 2008). 4

Finally, a difficulty that Honduras faces today is the ever-increasing use of Honduran territory as a transit point for cocaine on its way from South America to the US, and the organized crime infrastructure that comes with it. Many suggest that this leads to corruption of police and military forces and increases mistrust between government agencies who may become hesitant to share information about ongoing investigations (Bosworth 2010: 80). The apparent impunity faced by local criminals and the seeming weakness of state institutions to respond to crises perpetuates the notion of Honduras as an ideal location to carry out illicit activities.

\subsection{CASE 2. EL SALVADOR}

For most of the $20^{\text {th }}$ century, El Salvador was ruled by military forces with the consent of the economic elites who benefited from the order and societal control that the military provided. Organized state oppression of Salvadorans goes back at least as far as 1932 when the military killed approximately 30,00o indigenous people in an uprising-a nationally traumatizing event known as La Matanza (The Slaughter). Hume observes that the indiscriminate use of top-down violence that started with La Matanza, and continued in its wake, created a cycle of dependence between economic elites and the military, where their power/protection quid pro quo purposefully blocked political and social change and served as a warning to the public about the conse-

4. There is a rich and interesting debate within academia as to how broadly or narrowly to define "failed state", "holocaust", "genocide" and other terms connoting extreme circumstances. Such terms should be used with great care and it is beyond the scope of this paper to enter into the range of opinion on the subject or argue if its application to Honduras is appropriate. That said, the following is worth considering: "If (as we concede) there is a moral risk in overextending the concept of 'genocide' into spaces and corners of everyday life where we might not ordinarily think to find it (and there is), an even greater risk lies in failing to sensitize ourselves." (Scheper-Hughes and Bourgois 2004: 20) 
quences of dissent (2008: 70). In this sense, violence was used by the state as a functional means to an end.

Over the next 50 years, rigged elections and extreme inequality did little to alleviate political discontent or resolve social injustices. Tensions grew throughout the late 1960 s and 1970s, especially as communist ideals took root throughout Latin America. In 1979 a civil-military alliance overthrew the ruling forces and temporarily installed the Junta de Gobierno. The government quickly deteriorated when the military revealed its unwillingness to share power with civilians, many of whom subsequently defected and joined forces with the growing rural-based guerrillas. By 1980, the 5 previously autonomous guerrilla factions joined forces under the name Frente Farabundo Martí para la Liberación Nacional (FMLN) 5 and fought the government of El Salvador in a long and costly civil war. Neither side was able to win militarily despite, or possibly due to, significant external support on both sides. After a protracted military stalemate and a change in US foreign policy, the two sides signed peace accords on January 16, 1992. By the end of the war, approximately 75,00o people had been killed ${ }^{6}$, half a million were internally displaced and 1 million had fled the country; this, in a country of just 6 million people (CICS 2008: 1).

One major difference between El Salvador and Honduras in the post-Cold War era is that the Peace Accords are considered to be among the most successful in UN history, bringing real reforms to the nation including a demilitarized police force with a comparatively good reputation, civilian control of the military, and space for the political left. In 2009, the FMLN candidate for president won the national election, something unimaginable a decade earlier. As in Honduras, broad amnesty laws passed in the early 1990s have prevented human rights abusers from being held legally accountable. However,

5. Agustín Farabundo Martí Rodríguez was a leftist political activist in the early $20^{\text {th }}$ century and one of the leaders of the indigenous people's uprising that would end with La Matanza. After the movement's failure, Martí and the two other organizers were executed on orders of the military dictator at the time.

6. The estimate of victims is often quoted between 60,000 to 80,000 , with 75,000 being the most commonly cited. 
unlike in Honduras, El Salvador did purge military officers named in a UN truth commission.

Within the last decade, El Salvador has continuously courted a close relationship with the US, especially in its steadfast participation in the so-called Coalition of Willing which sent troops to Iraq in 2003. El Salvador was the last Latin American country to withdraw its troops and did so only after the U.N. mandate expired at the end of 2008. Approximately 1 in every 5 Salvadorans emigrate primarily to the US and remittances sent back to El Salvador make up 16\% of the national GDP. In Latin America, this is second only to Honduras where remittances make up $19 \%$ of GDP, but only $7 \%$ of the Honduran population resides abroad (World Bank 2011).

Domestically, 2012 has been a very exciting year in El Salvador where the Catholic Church brokered a peace agreement between the top two rival gangs, suddenly cutting the homicide rate in half. On

Box 3. The Salvadoran Gang Negotiations: An insider's perspective

In an original interview with Salvador Samayoa, former FMLN leader and public figure in the post-war era, he commented on the gang negotiations, the publicity it has received and why gangs may be ready to negotiate now:

"For 5 years, I was President of the National Council of Public Security from 1999 to 2004. During that time, I maintained a permanent dialogue with those same gang leaders [...] that they are talking to now. Nobody made a big deal out of it because I wasn't trying to make the news and I found ways to keep the dialogue private, but I always favor dialogue...[No one] is forgiving their sentences or reducing their jail time. Instead, what stands out is the age of the group. Because of their age, their kids are becoming adolescents...and they are starting to consider the fact that their kids are going to have the same life, where their only future is kill or be killed. And I think they have important reasons to start deactivating the slaughtering of one another." 
March 8, the Mara Salvatrucha and the Mara 18 agreed to stop killing each other in exchange for better prison conditions-though not reduced sentences-for their top leaders. Skepticism remains high and many fear that society will prove unwilling to give gang members a second chance. Some warn that the process has in fact empowered gangs as political actors who will now hold sway over elected leaders trying to maintain the peace (see for example Farah 2011). Official numbers suggest that the decrease in gang-related homicides has not led to an increase in other types of violence, such as disappearing people, despite early rumors to the contrary (Valencia, El Faro June 11, 2012).

Within the context of El Salvador, it is especially interesting that the process of negotiation between gangs is referred to not only as a "truce" but often as a "ceasefire" and a "peace process", recalling El Salvador's own recent history. Certainly, Central America watchers will be keeping a close eye on how the situation unfolds, but researchers interested in the transmission and reproduction of violence from past to present should pay special attention to the possibility that nonviolence could be transmitted and reproduced through the same channels. On a policy level, leaders from neighboring countries and international organizations such as the Organization of American States are also eagerly watching the process to see if it could serve as a model for other contexts.

\subsection{SUMMARY}

These case backgrounds are meant to highlight protracted periods of political violence and repression and their evolution to the present day. Both Honduras and El Salvador had an influx of firearms during the 1980 s and social fabric was corroded by the repressive political conditions on the ground. These factors are in some ways accounted for in Approach 1 and Approach 2, but further refinement of the theory of chronic violence to create a new mixed approach with objective indicators would correct for some of the flaws outlined in Chapter 2. Chapter 4 outlines what an integrated approach based on the theory of chronic violence could look like and proposes specific indicators to measure it over time. 


\section{PROPOSAL FOR AN INTEGRATED MODEL AND INDICATORS}

The approaches discussed in Chapter 2 each have strengths and weaknesses as to what they reveal about violence and how it is transmitted and reproduced through time. This paper argues that the theory of chronic violence, supported by a better understanding of gun possession and gun violence as proposed by Approach 1, would allow for a richer explanation of the causal relationship between past and present violence. Furthermore, the theory of chronic violence would benefit from clear indicators that could offer a snapshot of violence at any given time, predict its future direction or reveal information about its past evolution. It should be noted that this chapter is a proposal and a work in progress, but it recommends a new model to further understand violence with concrete indicators that would help track its evolution.

As previously mentioned, the definition of chronic violence is based on homicide rates that are twice the average for the country's income group sustained for over 5 years, in addition to "high levels" of nonfatal violence with active or tacit complicity from the state. One can assume that Pearce sought to use a flexible definition of chronic violence so that it would be adaptable to a variety of contexts. However, understanding chronic violence is especially useful so that single cases can be studied over time or various cases can be compared in order to assess its evolution and not just the causes of violence. Subjective understanding is ultimately less useful if it does not allow for easy comparison or tracking.

This paper proposes three concrete indicators that would be useful in the context of chronic violence to track it over time and make predictive observations, for example, about whether certain aspects of chronic violence are increasing or decreasing, beyond simply tracking homicide rates. The first suggested indicator is crime underreporting (4.1). This information is available through household surveys, such as LatinoBárometro, that are done regularly throughout Latin Ameri- 
ca. Statistics on crime underreporting are indicative of the degree of social silence around direct violence in a given society. The second suggested indicator looks at confidence in state institutions, specifically the judiciary (4.2a) and the police (4.2b). This is complementary to the first indicator but is not limited to only victims of crime. Furthermore, confidence in state institutions is a fundamental measurement of the health of a democracy. The third and most complex indicator tries to assess estimates of legal and illicit firearms (4.3), which should play a more prominent role in the theory of chronic violence.

\subsection{CRIME UNDERREPORTING}

Insofar as crime and violence are related, information about crime underreporting can be revealing in several ways. First, official homicide and crime reports combined with other data sources on the frequency of underreporting give a more realistic sense of the amount of direct violence taking place. Second, if "the most profound effect of crime is the way it undermines the relationship between citizens and their government" (Seligson and Booth 2010: 124, citing UNDP report), then data on underreporting exposes an important component of the relationship between citizens and government.

Table 5. Percentage of Crimes Reported

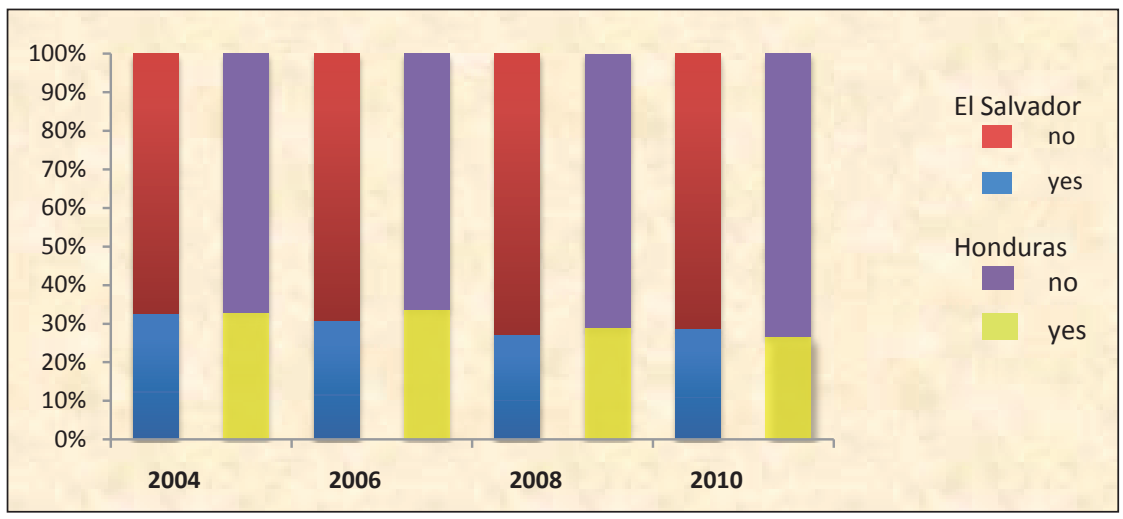

Source: Author's elaboration based on LatinoBárometro data 
Table 5 shows data from surveys in El Salvador and Honduras on crime reporting. If respondents affirmed being a crime victim within the last 12 months, they were then asked whether or not they had reported it (this is indicated in Table 5 by "yes" or "no"). The data suggests that approximately $70 \%$ of crimes are not reported in both $\mathrm{El}$ Salvador and Honduras, with only slight variation over time. Given that homicides are more likely than other crimes to be recorded (by police or the medical examiner) this data indicates that the number of non-fatal crimes is profound and pervasive. Moreover, this shows that there is a high degree of silence surrounding criminal acts, which could indicate both in increased tolerance for crime and a lack of trust in state institutions.

\subsection{CONFIDENCE IN STATE INSTITUTIONS: \\ THE JUDICIARY (4.2A) AND THE POLICE (4.2B)}

Confidence in the judiciary is an important measurement of how citizens relate to a state institution that is vital for a functioning democracy. Public confidence can be indicative of a standard to which citizens will hold their institutions (what they will and will not tolerate), how likely citi-

Table 6. Confidence in Judiciary

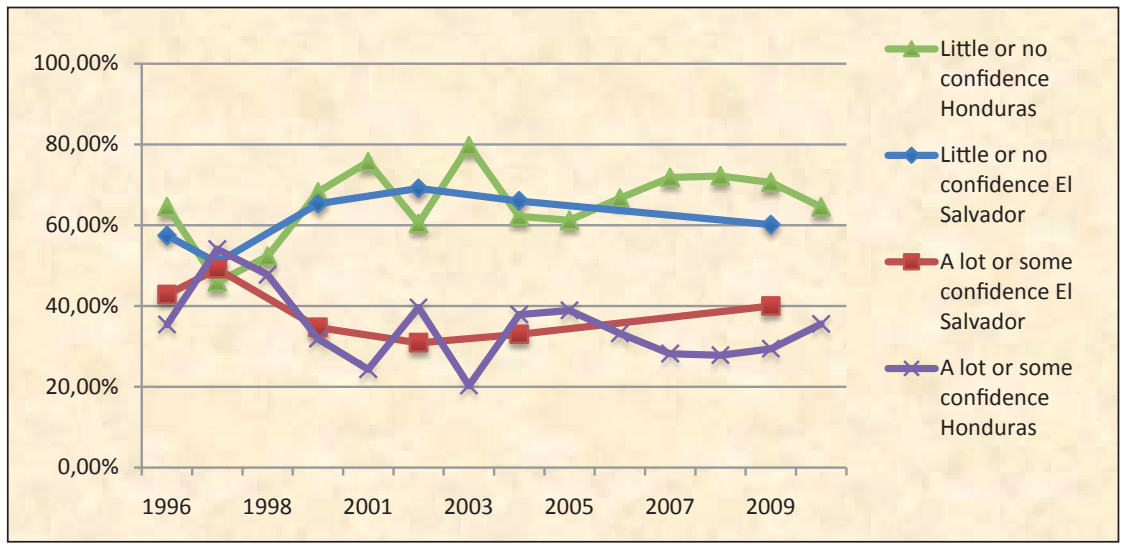

Source: Author's elaboration based on LatinoBárometro data 
Table 7. Confidence in police

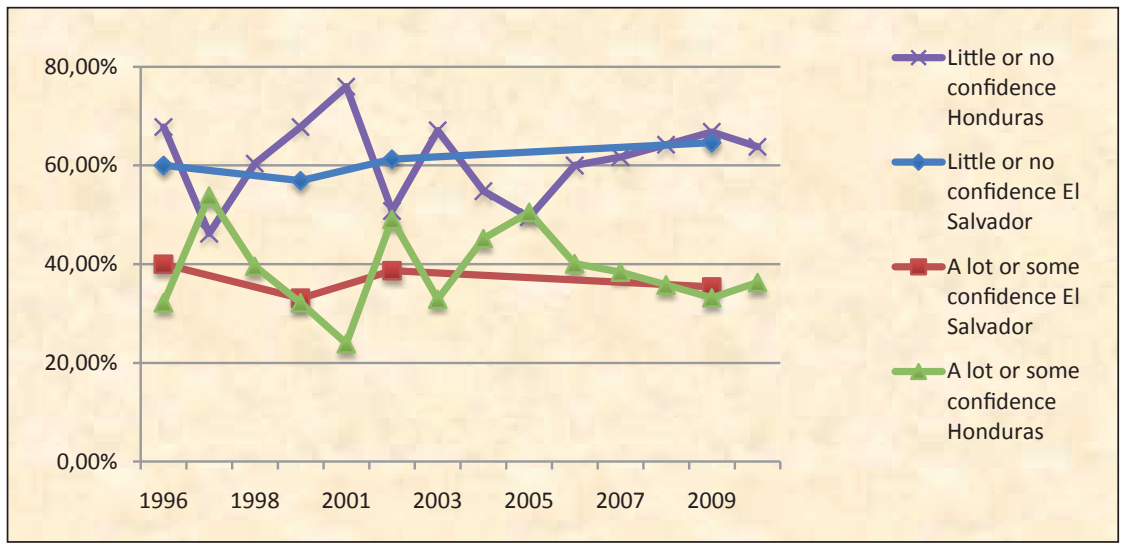

Source: Author's elaboration based on LatinoBárometro data

zens may be to comply with a ruling, perceptions of corruption and how responsive citizens feel the state is to their needs. Of course, confidence in police must go hand in hand with a solid judiciary, but a well-functioning police force will not be very effective with a poor judicial system. The inverse, if it exists, is not necessarily true. Furthermore, confidence in the judiciary can be indicative of perceptions of impunity and whether citizens feel that everyone gets equal treatment under the law.

Table 7 shows the level of confidence that Salvadorans and Hondurans have in their respective judiciaries over time. Emerging from the civil war, El Salvador's judiciary topped the UN's list of institutions most in need of reform. After the 2009 coup in Honduras, scholars suggested that a sense of pervasive impunity and lack of capacity in the judicial system over time likely contributed to the problem.

The absence of trials for military personnel who had committed human rights abuses during the authoritarian governments created a sense of impunity that spread through society and in security organizations. Honduran police and citizens have not internalized the idea of "rule of law", the imposition of rights and the supremacy of the legal system. The penal system is arbitrary [...]. (Benitez Manaut and Diamant 2010: 147-8, author's translation) 
Public perception data suggests that confidence in the Salvadoran judiciary has slightly improved over time, possibly indicating improvements that were a direct result of the peace accords. Honduran opinion has varied more, but it is interesting to note that there was not a significant change in confidence in the judiciary after the 2009 coup. Table 8 shows the level of confidence in the police, which mirrors the overall trend levels for the judiciary, though with slightly less variation.

\subsection{IMPROVED ESTIMATES ON LEGAL AND ILLICIT FIREARMS}

Researchers and policymakers are regularly frustrated with the dearth of reliable information on the movement of small arms and light weapons (SAWL) and the inability to improve global tracing or registration systems. In preliminary talks leading up to the 2012 UN Arms Trade Treaty (ATT) negotiations, there were important discussions concerning efforts to create a UN SAWL registry or to include it in an ATT. Such a registry would be vital for improving policies geared at lowering homicide rates, especially since guns are a significant cause of fatalities in El Salvador and Honduras.

Unfortunately, the ATT negotiations ended without advancements with regard to conventional weapons or SAWL. Fragmentary information along with general estimates continue to be the best available data. Building a database of legal and illicit firearms for the region would be ideal, or at least best estimates of said data. However, creating such a database will need to be left to future research. In the meantime, a few points stand out and would be worth further exploration. Godnick, Muggah and Waszink observed that tens of thousands of US weapons exports bound for Central America were categorized as hunting and sporting weapons. As the state continues to be incapable of controlling mounting security issues, the wealthy increasingly turn to private security companies for protection who need larger and more diverse arsenals. The authors note that "[s]ocio-economic conditions in Central America preclude the existence of a sufficiently large leisure class who would purchase the quantity of weaponry solely for hunting 
and sports shooting" and they fear such weapons are being used by private security groups (2002: 7).

Secondly, and to this point, the authors note that as of 2002 over 12 private security companies had acknowledged having AK-47s in their inventories despite the fact that only the military is permitted to have such weapons (Ibid.: 24). By 2012, the market price of an AK-47 in Honduras was only $\$ 200$ US, compared to $\$ 400$ in the rest of Central America, \$450 in Mexico, and \$500 in the US (www.gunpolicy.org). In basic economic terms, the low cost in Honduras suggests that the market has enough supply to drive the price down.

\subsection{POLICY IMPLICATIONS}

The above indicators provide a way to measure the evolution of violence in situations of chronic violence, while correcting for the subjective nature of the originally proposed theory. The capacity to measure certain features of chronic violence is particularly useful in assessing the successes or failures of public policies that are continually under review for the region. Though further research is needed, the information presented here supports calls for policies that seek more than short-term results through the use of the military for domestic policing or an increased financial investment in anti-drug policies.

As Cuesta (2009) has argued in his research on social capital and crime, it is necessary to separate out distinctive causal links concerning violence in order to create effective social policies with any hope of success. In designing effective public policies to counter violence of any kind, the source of the violence and the aim of the policy must go hand in hand. Looking at some existing examples, there are top-down policies that try to resolve government corruption, impunity or otherwise weak institutions and bottom-up policies that focus on citizen security and community relationships, especially in areas of increased social exclusion.

Below (Table 8), we assess the International Commission Against Impunity in Guatemala (CICIG), which Shifter (2012) argues should be applied to Salvadoran and Honduran contexts, as well as two bot- 
tom-up approaches towards reduction in gang-related violence that were successful in the U.S. before being exported to other countries around the world. After explaining the details of each program and their potential applicability to other contexts in general, we look at what policies are currently being implemented in El Salvador and Honduras and where they might be improved upon.

Table 8. Institutional Reform and Violence Reduction Public Policies

\section{International Commission Against Impunity in Guatemala (CICIG)}

This top-down approach came out of an agreement between the government of Guatemala and the United Nations Program for Development (UNPD). It allows for UN oversight of high-profile cases of corruption and technical advice to dismantle illicit security organizations. Their mandate also allows for recommendations concerning constitutional, judicial and other institutional reforms. Backing from the UNPD not only provides funding such undertakings but lends integrity to the process. The CICIG can also directly file complaints against public officials and provide improved witness protection for those willing to cooperate.

\section{Applicability:}

- Successful prosecution in corruption cases will help rebuild citizen trust in the judiciary.

- Potential to bring about permanent systemic change.

\section{Challenges:}

- Will not bring about a reduction in violence in the short term.

- Dependent on external funding.

- Dependent on external oversight and capacity in the short term.

\section{Operation Ceasefire}

This community-based approach to reducing gun violence began in Boston in the 1990 s and has since been applied in over 70 US cities, while receiving plenty of international attention. Its creator, David Kenney, considers that no amount of law enforcement or zero-tolerance political policies can solve the problem of violence. Instead, his program aims to reduce gun violence through a 2-pronged approach: crack down on the supply of weapons and meet with gang members to talk. Though it may sound simple, a team identified key gang leaders in the most violent or at risk areas and brought them together with police and community members. The police, in effect, called a ceasefire and promised to focus 
all their attention on the first gang to break the ceasefire by participating in gun violence. Community members also shared stories of how violence had affected their lives. Both the police and the community members placed special emphasis on the fact that they did not hate the gang members, indirectly reducing their sense of isolation in the community.

Inevitably, when the ceasefire was broken, the police would follow through on their threats to focus special attention on the whole gang who broke the ceasefire, not just the individual responsible. This process would be repeated over and over again with the sole intention of reducing gun violence and the indirect outcome of rebuilding relationships within the community. Key to the success of this program was that consequences were clearly outlined in advanced and consistently followed through on by the police. The program creator has also stated that once progress has been made on the initial goal (reducing gun violence); it can be expanded to other specific goals one at a time (e.g., not recruiting children, etc.).

\section{Applicability:}

- Ideal for under-funded violence reduction programs and police departments because it is largely based on dialogue.

- Humanizes gang members and police to one another; gives gang members a role in the community.

- Incentivizes internal "policing" as entire gangs will be "punished" for an individual's misdeed.

- Feasible because of narrow focus.

Does not try to dismantle entire gangs; just reduce one kind of violence at a time.

- Simple and high success rate.

\section{Challenges:}

- Must have the institutional capacity to follow through on threats consistently, or possibility to design programs around existing capacity. - Must have coordination between districts and police departments in order to share information and respond consistently.

- Targeting high-risk areas and specific kinds of violence inevitably deprioritizes others.

\section{Office of Gang Reduction and Youth Development, Los Angeles, CA}

This community-based approach was put into place in 2007 and has resulted in a $33 \%$ drop in homicides in areas where it has been implemented. Various efforts in the city to combat gang-related crime and violence were completely restructured into a single office that could coordinate and implement a comprehensive and multijurisdictional program. The initiative moved away from 
indiscriminate suppression tactics (somewhat analogous to the failed Mano Dura programs in El Salvador and Honduras) when city officials realized that they could not "arrest their way out" of the problem.

Driven by empirical data collection and analysis, the office identified and micro-targeted hotspots and at risk groups, as well as specific times of day and days of the week when crime spiked. They designed programs accordingly, such as offering cultural activities for all ages in parks where gangs tended to congregate, and integrated school and community groups as well as multigenerational family members. When incidents of violence occurred, officials responded in teams of three from the local government, law enforcement and gang intervention specialists. These teams paid special attention to preventing retaliation by talking to those affected by a violent incident within the first two weeks after it happened. This was a key tactic in preventing or reducing endless cycles of retaliatory violence and homicide. Their stated goal was not crime reduction but norm transformation and making everyone a stakeholder in their community.

\section{Applicability:}

- Empirical data allows for easy tracking of crime and violence in order to appropriately target zones and people at risk.

- The impact of data driven programs can be easily measured, which can facilitate transparency and accountability.

- Focus on norm transformation vital for permanent change and a key aspect of treating chronic violence.

- Takes into account a diverse set of community networks, including multigenerational and transnational families and support systems.

\section{Challenges:}

- Data collection may be fragmented or unreliable.

- Requires large-scale capacity to coordinate efforts through a single office which will ensure the use of a clear and consistent framework.

Source: Author's elaboration based on information from http://cicig.org/; http://www.nij.gov/; and Céspesdes 2012 


\subsection{A. CURRENT PUBLIC POLICIES IN EL SALVADOR}

In the summer of 2012, the municipality of Santa Tecla put in play a pilot program entitled "Seguridad Inalámbrica" or Wireless Security. 500 security cameras were installed in high crime areas and police were given 95 hi-tech phones that allowed them to communicate and coordinate instantly as well as collect better data on crimes committed. Santa Tecla noted a $36 \%$ drop in crime, prompting mayors from other areas to sign on to the program. Seven other municipalities will undergo a 6-month trial run with similar programs.

Similar crime mapping was a crucial first step in LA's successful crime and violence reduction plan, and should be seen as a first phase for these communities. Relevant authorities should look to the LA model in order to design programs that expand on the uses for this new capacity to collect data and improve communication. Now that more reliable data will become available, interventions can be tailored to specific areas, age groups, and even times of the day to get the highest benefit from the information gathered. The disaggregated data should be made public, as well as changes in crime rates over time, which will help restore public confidence in the police.

\subsection{B. CURRENT PUBLIC POLICIES IN HONDURAS}

President Lobo has called for a purge of corrupt police officials and an overall reform of the national police. In the fall of 2012, 400 police officers and relevant civilian workers underwent confidence tests to with polygraphs. 124 people, or $31 \%$, failed the polygraph including 5 police commissioners and 14 deputy commissioners and all have been fired or are under further investigation. A total reform of the Honduran national police is clearly in order and purging corrupt officers is a necessary step. However, other plans in the works to strengthen institutional capacity in Honduras or to boost citizen security may have too broad a scope to be able to be realistically implemented at once.

The purge was designed at the request of the President by the Commission on Public Security Reform (CRSP), a newly created office with 
local and international oversight and the stated aim of making recommendations regarding profound structural reforms in Honduras. Their most recent recommendations include the creation of a Selection and Evaluation System, an Organic Law of the National Police, a draft bill for the Police Profession, a draft bill for the Civil Servant Profession, draft reforms to the Law of the Attorney General, draft reforms to the Jurisdiction Law for the Chamber for Administrative Litigation, draft reforms to the Judicial Council Law and to the Judicial Profession. CRSP has also recommended revising Honduras' gun laws which currently allow any adult to have 5 personal weapons.

Deep structural reforms are needed in Honduras and all of the recommendations made by CRSP are undoubtedly necessary. However, it is unclear that there are the resources or long-term political will to implement all of these reforms at once. The government may need to prioritize these top-down needs as well as design a thoughtful bottomup approach to address the fact that when 2012 data becomes available, Honduras will likely far surpass El Salvador as the most violent country in the world in terms of homicides.

\subsection{SUMMARY}

Considering the dual urgencies of reducing violence and slowing down its transmission in the short term and reforming institutions in the mid to long term, public policies are ultimately needed that will address both bottom-up and top-down structures. This section has suggested ways to operationalize the theory of Chronic Violence and overcome its subjectivity with the addition of indicators that measure intangible aspects of violence and its consequences. By then outlining some existing public policies in various nations and considering their application to current policies in El Salvador and Honduras, a very initial step in what calls for continued research has been made. A better understanding of the some of the causes of current violence can help to build upon existing discourse and suggest ways to improve public policies that may otherwise not be geared towards the root of the problem. 


\section{CONCLUSION}

Pervasive violence in El Salvador and Honduras is extremely troubling and appears to be worsening. The existing literature, systematized into Approach 1 and Approach 2, each appear to be insufficient on their own in explaining and operationalizing the causal connection between current violence and past political violence. By breaking down each approach and carefully assessing its parts, the strengths and weaknesses of each of each model becomes apparent. Thus, to the extent that current non-political violence is related to past political violence, we are better able to understand how this is so and propose new ways to operationalize this relationship and measure it over time.

Using the theory of Chronic Violence, and identifying protracted political violence as a trigger, contributes to our understanding by clarifying the relationship between the tangible and intangible legacies of political violence and the present. Though this research is ongoing, we suggest three indicators (crime underreporting, confidence in state institutions and estimates on legal and illicit firearms) that can be used to operationalize and measure contexts of Chronic Violence more precisely. Constructing a functional model to measure Chronic Violence that removes the subjective opinion of the researcher will allow for better comparisons across cases or within a single case over time.

Further research on this subject could delve more deeply into crafting effective public policies based on an improved understanding of Chronic Violence. This could be done by looking at cases where protracted political violence did not lead to alarming rates of non-political violence, such as in Nicaragua, or tailoring best practices from other contexts of Chronic Violence to consider their broader applicability. Additionally, the model proposed in this paper could be relevant beyond Central or even Latin America and further research could confirm or falsify its explanatory value in other cases.

Violence is complex and is caused by many factors. Causal claims regarding the connection between past and present violence cannot be 
taken at face value and their links must be closely assessed. While it is clear that there is no single policy solution to such complex problems, each attempt will be more effective if it incorporates a more careful analysis of the tangible and intangible legacies of past violence. Despite all its uncertainties, the calm in the wake of the gang ceasefire in El Salvador provides a real opening to implement thoughtful policies beyond those gang-related, and worsening violence in Honduras demands prompt responses that are more effective at targeting root causes.

\section{REFERENCES}

Adams, Tani Marilena. 2011. "Chronic Violence and Its Reproduction: Perverse Trends in Social Relations, Citizenship and Democracy in Latin America.” Woodrow Wilson International Center for Scholars. http://www.wilsoncenter.org/ ChronicViolence [Last accessed 11.09.12]

- Allison, Michael E. 2006. "The Transition from Armed Opposition to Electoral Opposition in Central America." Latin American Politics \& Society 48 (4) (November 16): 137-162.

Benítez Manaut, Raúl and Diamint, Rut. "La cuestión military: El golpe de Estado en Honduras como desafío a la democracia y al sistema interamericano.” Nueva Sociedad no. 226 (March-April 2010). http://132.248.9.1:8991/hevila/Nuevasociedad/2010/ no226/11.pdf [Last accessed 17.06.12]

- Bosworth, James. 2010. "Honduras: Organized Crime Gaining Amid Political Crisis." Woodrow Wilson International Center for Scholars. http://int.wilsoncenter.dev6.fayze2.com/sites/default/ files/Bosworth.FIN.pdf [Last accessed 11.09.12]

- Cardenal Izquierdo, Ana Sofia. 2008. “¿Son las guerras civiles responsables del crimen en Centroamérica? Revista CIDOB d'Afers Internacionals 81: 67-90.

- Castellanos, Julieta. 2000. Honduras: armamentismo y violencia. Tegucigalpa: Fundación Arias para la Paz y el Progreso Humano. 
- Center for Justice and Accountability. (n.d.) "Battalion 316: Torture \& Forced Disappearance.” http://www.cja.org/article. php?list=type\&type $=254$ [Last accessed 12.09.12]

Central Intelligence Agency, (n.d.). "The World Factbook." https:// www.cia.gov/library/publications/the-world-factbook/fields/2172. html [Last accessed 12.09.12]

- Centre for International Cooperation and Security (CICS). 2008. Desk Review: Disarmament, Demobilization and Reintegration (DDR) and Human Security in El Salvador. University of Bradford. Céspedes, Guillermo. 2012. "Improving Citizen Security in Central America: Options for Responding to Youth Violence.” Speech, Wilson Center. October 18. http://wilsoncenter.net/event/ improving-citizen-security-central-america-options-forresponding-to-youth-violence [Last accessed 12.11.12]

- Colak, Alexandra Abello, and Jenny Pearce. 2009. "Security from Below' in Contexts of Chronic Violence." IDS Bulletin 40 (2) (March): 11-19.

- Cruz, José Miguel. 2011. "Criminal Violence and Democratization in Central America: The Survival of the Violent State." Latin American Politics and Society 53 (4): 1-33.

- Cuesta, José. 2009. "Social capital, crime and welfare: the cases of Colombia and Honduras." In Social Capital and Peace Building: Creating and resolving conflict with trust and social networks, ed. Michael Cox, 37-56. Oxon: Routledge.

Dickson-Gómez, Julia. 2002. “The Sound of Braking Dogs: Violence and Terror Among Salvadoran Families in the Postwar." Medical Anthropology Quarterly 16 (4). New Series (December 1): 415-438.

- Economist. 2012. "Violence in Honduras: The eye of the storm." June 16. http://www.economist.com/node/21556914 [Last accessed 12/09.12]

- Farah, Douglas. 2011. "Organized Crime in El Salvador: The Homegrown and Transnational Dimensions." Woodrow Wilson International Center for Scholars. http://wilsoncenter.net/sites/ default/files/Farah.FIN1.pdf [Last accessed 11.09.12] 
" Fearon, James. 2007. "Iraq's Civil War." Foreign Affairs. March/ April. http://www.foreignaffairs.com/articles/62443/james-dfearon/iraqs-civil-war [Last accessed 12.09.12]

- Frank, Dana. 2012. "In Honduras, a Mess Made in the U.S." New York Times, January 26. http://www.nytimes.com/2012/o1/27/ opinion/in-honduras-a-mess-helped-by-the-us.html [Last accessed 12.09.12]

- Hume, M. 2008. "The Myths of Violence: Gender, Conflict, and Community in El Salvador." Latin American Perspectives 35 (5) (September 1): 59-76.

- Hume, Mo. 2009. "Researching the Gendered Silences of Violence in El Salvador." IDS Bulletin 40 (3): 78-85.

- Galtung, Johan. 1996. Peace by Peaceful Means: Peace and Conflict, Development and Civilization. London: Sage.

- Geneva Declaration Secretariat. 2011. Global Burden of Armed Violence 2011. http://www.genevadeclaration.org/measurability/ global-burden-of-armed-violence/global-burden-of-armedviolence-2011.html [Last accessed 06.11.12]

- Godnick, Willian, Robert Muggah and Camilla Waszink. 2002. "Stray Bullets: The Impact of Small Arms Misuse in Central America." Small Arms Survey Occasional Paper No. 5. http:// www.smallarmssurvey.org/fileadmin/docs/B-Occasional-papers/ SAS-OPo5-Central-America.pdf [Last accessed 12.09.12]

- Grasa, Rafael. 2010. Cincuenta Años de Evolución de la Investigación para la Paz: Tendencias y propuestas para observar, investigar y actuar. Barcelona: Oficina de Promoción de la Paz y de los Derechos Humanos, Generalitat de Cataluña.

n Laurance, Edward J. and William H. Godnick. 2000. "Weapons Collection in Central America: El Salvador and Guatemala. "http:// www.hawaii.edu/hivandaids/Weapons_Collection_in_Central_ America_El_Salvador_and_Guatemala.pdf [Last accessed 11.09.2012]

Marbley Martínez, Dina. 2006. "Proyecto Abordando El Trafico Ilícito Desde Una Perspectiva Regional: Diagnóstico-El Salvador.” Fundación de Estudios Para la Aplicación del Derecho. 
Menjívar, Cecilia and Néstor Rodgriquez, eds. 2005. When States Kill: Latin America, The U.S., and Technologies of Terror. Austin: University of Texas Press.

v Moser, Caroline. 2004. "Urban Violence and Insecurity: An Introductory Roadmap." Environments\&Urbanization 16 (2) (Ocobter).

- O'Shaughnessy, Laura Nuzzi, and Michael Dodson. 1999. "Political Bargaining and Democratic Transitions: A Comparison of Nicaragua and El Salvador." Journal of Latin American Studies 31 (1) (February 1): 99-127.

- Panting, César. 2012. "Honduras está viviendo el holocausto de sus jóvenes por crímenes.” La Prensa, May 8. http://www.laprensa. $\mathrm{hn} /$ Secciones-Principales/Honduras/Apertura/Honduras-estaviviendo-el-holocausto-de-sus-jovenes-por-crimenes [Last accessed 12.09.12]

- Pearce, Jenny. 1998. "From Civil War to 'Civil Society': Has the End of the Cold War Brought Peace to Central America?" International Affairs (Royal Institute of International Affairs 1944-) 74 (3) (July 1): $587-615$.

-. 2007. "Violence, Power and Participation: Building Citizenship in Contexts of Chronic Violence." Institute of Development Studies Working Paper 274.

-. 2010. "Perverse State Formation and Securitized Democracy in Latin America." Democratization 17 (2) (April): 286-306.

- Pine, Adrienne. 2008. Working Hard, Drinking Hard. Berkley and Los Angeles: University of California Press.

- Ramsey, Geoffrey. 2011. "Cable: Honduran Military Supplied Weaponry to Cartels". InSight Crime, April 25. http://www. insightcrime.org/news-analysis/cable-honduran-militarysupplied-weaponry-to-cartels [Last accessed 06.11.12]

- Richani, Nazih. 2010. "State Capacity in Postconflict Settings: Explainaing Criminal Violence in El Salvador and Guatemala." Civil Wars 12 (4): 431-455. 
- Rodgers, Dennis. 2006. "Living in the Shadow of Death: Gangs, Violence and Social Order in Urban Nicaragua, 1996-2002." Journal of Latin American Studies 38 (2) (May 1): 267-292. - Rodgers, Dennis, Robert Muggah and Chris Stevenson. 2009. "Gangs of Central America: Causes, Costs and Interventions." Small Arms Survey Occasional Paper 23.

- Ruhl, J. Mark. 2010. “Honduras Unravels.” Journal of Democracy 21 (2): 93-107.

- Salomon, Leticia. 1993. La Violencia en Honduras 1980-1993. Tegucigalpa: Centro de documentación de Honduras.

- Samayoa, Salvador. 2012. Unpublished interview by Rachel Meyer. June 15, Skype.

- Scheper-Hughes, Nancy and Philippe Bourgois, eds. (2004) Violence in War and Peace: An Anthology. Malden: Blackwell Publishing.

- Seligson, Mitchell A., and John A. Booth. 2010. "Crime, Hard Times, and Discontent.” Journal of Democracy 21, no. 2 (April): 123-135.

- Shifter, Michael. 2012. "Countering Criminal Violence in Central America." Council on Foreign Relations. http://www.cfr.org/ central-america/countering-criminal-violence-central-america/ p27740 [Last accessed 11.09.2012]

- Stohl, Rachel and Doug Tuttle. 2008. "The Small Arms Trade in Latin America." NACLA Report on the Americas. 14-20.

- Transparency International. n.d. Corruptions Perceptions Index. http://www.transparency.org/research/cpi/overview [Last accessed 12.09.12]

n United Nations Office on Drugs and Crime, 2010. "Homicide Statistics." http://www.unodc.org/unodc/en/data-and-analysis/ homicide.html [Last accessed 12.09.12]

- Valencia, Roberto. "100 días de tregua, 100 días con ocho asesinatos menos." El Faro, June 11, 2012. http://www.elfaro.net/ es/201206/noticias/8842/ [Last accessed 12.09.12]

- Valenzuela, Pedro. "Reflexiones Sobre Interpretaciones Recientes de la Violencia en Colombia." Convergencia 30, 125-146. 
nolf, Sonja. 2009. "Subverting Democracy: Elite Rule and the Limits to Political Participation in Post-War El Salvador." Journal of Latin American Studies 41 (03) (August 25): 429.

n World Bank. 2008. "Urban Crime and Violence in LAC: Status Report on Activities." http://siteresources.worldbank.org/ EXTLACREGTOPURBDEV/Resources/ViolencebrochureFINAL. pdf [Last accessed 12.09.12]

-2011. "Migration and Remittances Factbook 2011". Second Edition. http://siteresources.worldbank.org/INTLAC/Resources/ Factbook2011-Ebook.pdf [Last accessed 12.09.12] 


\section{ICIP WORKING PAPERS SUBMISSION GUIDELINES:}

\section{International Catalan Institute for Peace (ICIP)}

- The principle purpose of the ICIP is to promote a culture of peace in Catalonia as well as throughout the world, to endorse peaceful solutions and conflict resolutions and to endow Catalonia with an active role as an agent of peace and peace research. The ICIP, seeking consistency between ends and means, is governed by the principles of promoting peace, democracy, justice, equality and equity in relationships between individuals, peoples, cultures, nations and states. It holds the aim of working for human security, disarmament, the prevention and peaceful resolution of conflicts and social tensions, and strengthening the roots of peace and coexistence, peace building and advocacy of human rights.

\section{Objectives of the Publication}

- The ICIP wants to create an open forum on topics related to peace, conflict and security. It aims to open up debate and discussion on both theoretical and contemporary issues associated with the pursuit and maintenance of peace in our world. It strives to connect an eclectic group of voices including career academics, PhD students, NGO representatives, institutional representatives, and field workers and field writers to celebrate ground-breaking and constructive approaches to peace and conflict resolution.

\section{Scope of the Publication (List of Themes)}

- The ICIP is interested in works related to peace, conflict and security research. It aims to provide an innovative and pluralist insight on topics of methodology of peace research, the history and development of peace research, peace education, 
peace-keeping and peace-creating, conflict resolution, human security, human rights, global security, environmental security, development studies related to peace and security, international law related to peace, democracy, justice and equality, disarmament, gender, identity and ethics related to peace, science and technology associated with peace and security.

\section{Audience:}

- The ICP aims to provide accessible, valuable and well-researched material for all those interested in the promotion of peace. Our audience includes fellow academics and researchers, student of peace ands security, field workers, institutional and governmental representatives as well as the general public.

\section{The review process}

- Peer reviewed. Submissions should be sent directly to the series editor (recerca.icip@gencat.cat), who will check whether the paper meets the formal and general criteria for a working paper and will commission a review.

The review procedure is double-blind. The series editor will choose two anonymous reviewers, generally from the Editorial Board, but may also commission an external review from outside the ICIP.

- Reviewers are asked to write a review within a month after having received the paper. Reviews should clearly indicate one of four options: (1) accept without changes; (2) accept with minor changes; (3) allow for resubmission after major changes (4) reject. Options 2 to 4 require some detailed comments. If a paper is accepted (option 1 or 2), reviewers are kindly asked to help authors correct minor linguistic or other errors by making notes in the manuscript. If they use the track changes function for this purpose they should make sure that their comments are anonymized. 


\section{Who may submit working papers?}

- The main criterion for the submission of Working Papers is whether this text could be submitted to a good academic journal.

- ICIP staff and other fellows and visitors affiliated with the ICIP are expected to submit a working paper related to their research while at the ICIP.

\section{Submission System}

- All submissions can be made to the ICIP e-mail address: recerca.icip@gencat.cat with Working Papers - submission in the subject line.

\section{Author Biographical Statement}

- Authors must all provide a short biographical note including full name, affiliation, e-mail address, other contact information if necessary and a brief professional history. This information should be provided on a separate sheet with the title. All other personal references should be removed from the submission to ensure anonymity.

\section{Abstract}

- All papers must include English language abstracts (150 words max.)

\section{Keywords}

n A list of four to six keywords is also required.

\section{Language and Style}

- Authors may submit in Catalan, Spanish or English. The submission must be clearly written and easy to follow with headings demarcating the beginning of each section. Submission must in be Arial 11, double spaced and pages must be numbered. 
- Papers should not be longer than 15.000 words (incl. footnotes and references). Longer papers may be returned with a request to shorten them. Papers that require more extensive presentation of data may add these in an appendix that will count separately. Appendices should, however, present data in a reader-friendly and condensed format.

- Papers that will require extensive linguistic editing will not be accepted for review. Minor linguistic corrections (as well as required revisions) suggested by the reviewer must be implemented by the author before the final editing of the paper.

\section{Footnotes}

- Footnotes may be used to provide the reader with substantive information related to the topic of the paper. Footnotes will be part of the word count.

\section{References}

- The Harvard author-date system. In this system, sources are briefly cited in the text, usually in parentheses, by author's last name and date of publication. The short citations are amplified in a list of references in alphabetical list, where full bibliographic information is provided. Bibliographic references must follow The Chicago Manual of Style ( $15^{\text {th }}$ edition). See a Chicago-Style citation quick guide at:

http://www.chicagomanualofstyle.org/tools_citationguide.html Citation generators:

http://www.workscited4u.com/

http://citationmachine.net/ 


\section{ICIP WORKING PAPERS}

\section{$2012 / 4$}

Las posiciones de los diferentes grupos políticos israelíes sobre la resolución de la situación de los Refugiados by Aritz García Gómez (available in spanish)

\section{$2012 / 3$}

Els esperantistes catalans. Un colllectiu pacifista en un món global

by Hèctor Alòs Font

(available in catalan)

\section{$2012 / 2$}

Autonomía comunitaria y caciquismo: identidad étnica, control social y violencia en una comunidad mixe de Oxaca by Ignacio Iturralde Blanco (available in english and spanish)

\section{$2012 / 1$}

The analysis of the framing processes of the Basque peace movement: The way Lokarri and Gesto por la Paz changed society by Egoitz Gago Anton (available in catalan and english)

\section{$2011 / 8$}

New developments of peace research. The impact of recent campaigns on disarmament and human security by Javier Alcalde and Rafael Grasa (available in english)

\section{$2011 / 7$}

Segregation and the onset of civil war by Lesley-Ann Daniels

(available in catalan and english)

\section{$2011 / 6$}

Mechanisms of Neo-colonialism. Current French and British influence in Cameroon and Ghana by Diana Haag (available in catalan and english)

\section{$2011 / 5$}

Una anàlisi comparativa de la despesa militar espanyola en el molt llarg termini (1850-2009) by Alonso Herranz, Oriol Sabaté and Gregori Galofré-Vilà

(available in catalan and english)

\section{$2011 / 4$}

El foro social mundial y los movimientos antisistémicos by Jordi Calvo (available in catalan and english)

\section{$2011 / 3$}

Cultural Relativism in the Universal Periodic Review of the Human Rights Council by Roger Llovet Blackburn (available in catalan and english) 

INTERNATIONAL

CATALAN

INSTITUTE

\section{FOR PEACE}

GRAN VIA DE LES CORTS CATALANES 658, BAIX

08010 BARCELONA (SPAIN)

T. +3493554 4270 | F. +34935544280

ICIP@GENCAT.CAT | WWW.ICIP.CAT 